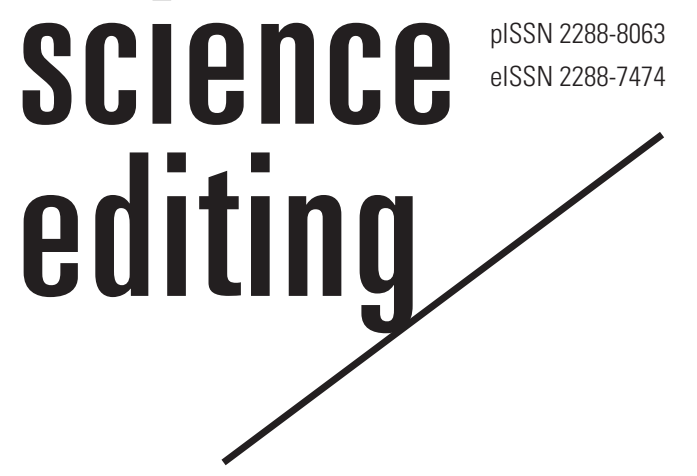

\title{
Korean court cases regarding research and publication ethics from 2009 to 2020
}

\author{
Ju Yoen Lee \\ School of Law, Hanyang University, Seoul, Korea
}

Abstract

Research and publication misconduct may occur in various forms, including author misrepresentation, plagiarism, and data fabrication. Research and publication ethics are essentially not legal duties, but ethical obligations. In reality, however, legal disputes arise over whether research and publication ethics have been violated. Thus, in many cases, misconduct in research and publication is determined in the courts. This article presents noteworthy legal cases in Korea regarding research and publication ethics to help editors and authors prevent ethical misconduct. Legal cases from 2009 to 2020 were collected from the database of the Supreme Court of Korea in December 2020. These court cases represent three case types: 1) civil cases, such as affirmation of nullity of dismissal and damages; 2) criminal cases, such as fraud, interference with business, and violations of copyright law; and 3) administrative cases related to disciplinary measures against professors affiliated with a university. These cases show that although research and publication ethics are ethical norms that are autonomously established by the relevant academic societies, they become a criterion for case resolution in legal disputes where research and publication misconduct is at issue.

Keywords

Author misrepresentation; Data fabrication; Korean court cases; Plagiarism; Research and publication ethics

Received: January 19, 2021 Accepted: January 30, 2021

Correspondence to Ju Yoen Lee rosa729@hanyang.ac.kr

ORCID

Ju Yoen Lee

https://orcid.org/0000-0002-0190-0030

\section{Introduction}

Background/rationale: Research and publication misconduct may arise in various forms, including author misrepresentation, plagiarism, and data fabrication. As the term suggests, research and publication ethics are essentially ethical, not legal, obligations. Therefore, when misconduct in research and publication is at issue, the most appropriate and desirable solution is for the relevant academic community to resolve the issue itself.

The Supreme Court of Korea stated in its 2015Da5170 decision [1], which will be discussed below, "in cases where the issue of plagiarism arises regarding a specific thesis or dissertation, 
the matter is initially determined by the relevant academic field." The court declared that the academic community is fundamentally responsible for resolving issues of research and publication misconduct. In a recent case involving the sale of paintings by a famous singer, the Supreme Court also stated that the issue of who become(s) the author(s) in cases involving multiple people in the creation of works of art "should be resolved in a self-regulatory fashion within the realm of art by way of criticism and discourse. That said, judicial determination thereof must be limited to cases in which such controversy develops into a legal dispute and copyright has become the categorical subject matter of the lawsuit" [2]. In reality, however, legal disputes arise over whether research and publication ethics have been violated. Consequently, in many cases, misconduct in research and publication is determined in the courts.

Objectives: This article presents nine recent Korean court cases in which research and publication ethics were at issue. It will help researchers and academic journal editors in Korea prevent and manage research and publication misconduct appropriately.

\section{Methods}

Ethics statement: As this is not human-subject research, but an analysis of judicial precedents, neither approval by the institutional review board nor obtainment of informed consent was required.

Study design: This is a summary presentation of Korean judicial precedents related to research and publication misconduct.

Data sources: Judicial precedents were searched from the database of the Supreme Court of Korea. Nine court cases were summarized.

\section{Court Cases regarding Plagiarism}

First case: dismissal for plagiarizing a doctoral dissertation Supreme Court decision 2015Da5170 (decided October 27, 2016) [1], a landmark judgment on plagiarism, regards a case in which plagiarism in a doctoral dissertation was judged in court [3]. A government-funded research institute had hired a $\mathrm{PhD}$ holder as a researcher. The research institute later fired the researcher, alleging that she had committed plagiarism in her doctoral dissertation. The researcher filed a lawsuit against the research institute seeking affirmation of nullity of dismissal. Thus, at issue in the lawsuit was plagiarism in her doctoral dissertation.

Before this case went to court, the university that had awarded the doctoral degree to the researcher examined the doctoral dissertation and determined that the researcher had not committed plagiarism according to the university's regulations. However, the Korean Progressive Academy Council, upon a request made by the research institute to investigate this case, and the research institute's special investigation committee both determined that the researcher had committed plagiarism. The researcher argued that the final responsibility for verification of her doctoral dissertation in this case lay with the university that had awarded the degree, and the research institute and academic association had no authority to determine whether plagiarism had been committed in her doctoral dissertation. This led to the following questions: what were the criteria for determining whether she had committed plagiarism in her doctoral dissertation, and who had the final authority to determine whether plagiarism was committed or not?

In response to these questions, the Supreme Court answered that "plagiarism should be determined depending on the research ethics prevailing at the time a work of authorship was written. [...] Research ethics refer to a set of standards generally and universally accepted within the academic community that researchers need to comply with, and are not necessarily confined to the statutory definition under the regulation on research ethics." The court stated further, "in cases where the issue of plagiarism arises regarding a specific thesis or dissertation, the matter is initially determined by the relevant academic field. However, where plagiarism in a thesis or dissertation creates legal relations that cause friction and thus becomes the subject of judicial review, courts have the ultimate authority to decide whether plagiarism has occurred." Moreover, the court underlined, "The competent court is required to determine whether plagiarism occurred through rational methods, rather than being bound by the judgment of affiliated organizations of authors, thesis or dissertation examination bodies, academic societies, etc.; Provided, feedback from experts of the relevant academic field is sought during the determination process."

In this case, the researcher was suspected of plagiarizing 1) her own master's thesis as well as 2) the works of her dissertation supervisor and Japanese authors in writing her doctoral dissertation. Therefore, the Supreme Court distinguished conventional plagiarism (corresponding to the second example above) from self-plagiarism as an unconventional type of plagiarism (corresponding to the first example above) in its ruling.

First, the Supreme Court defined (conventional) plagiarism as "an act of using another person's work of authorship or original idea that does not pertain to general knowledge in the relevant field without properly indicating the source" (emphasis added) and ruled that plagiarism occurs "where an au- 
thor cited another person's work in his/her work without indicating the source and thereby made it difficult to distinguish the works, notwithstanding that the author collectively and comprehensively indicated the source of the cited work in the introduction or reference (other than the body) of his/her work." Furthermore, the court clarified that an author cannot avoid liability for plagiarism solely on the grounds of having followed previous practices, and the occurrence of plagiarism cannot be negated on the basis that the author being plagiarized gave his/her consent to the use of his/her work.

In particular, because the researcher was suspected of plagiarizing works written by Japanese authors and she defended herself by asserting that she and her supervisor had co-authored her supervisor's books, the Supreme Court enumerated the methods of citing sources to avoid plagiarism as follows: 1) where an author cites foreign literature he/she has translated in his/her work, the relevant foreign literature should be indicated as the source; 2 ) where an author cites translations of foreign literature in his/her work, the said foreign literature should be reasonably indicated as the primary source and the translation as the secondary source; and 3 ) in principle, an author bears a duty to indicate the source when citing parts of a previous work that was co-written in his/her work as well as when citing another co-author's work among compiled or combined works that were co-written.

Next, the Supreme Court clarified that self-plagiarism occurs when authors use parts of their previous works in subsequent work and 1) "fail to reference his/her previous works" or 2) "the parts newly added in the subsequent work did not contribute whatsoever to the development of the relevant academic field due to lacking originality, despite the author having indicated the sources of his/her previous works cited."

On the basis of the principles above, the Supreme Court found that the researcher had committed plagiarism by including parts of her supervisor's work in her doctoral dissertation without citing the source, adding that even if the supervisor had allowed her to use those parts without citing the source, this does not negate plagiarism. The court also found that the researcher's use of her master's thesis without referencing it constituted self-plagiarism. Finally, the court held that these facts were sufficient to uphold the researcher's dismissal.

Second and third cases: fraud cases relating to plagiarism Gwangju District Court decision 2019Godan1 104 (decided February 13,2020) concerns a criminal case regarding a plagiarized article. A professor was compensated for publication fees and received a research grant from his university after publishing a plagiarized article, which was a translation of an article written in a foreign language and published overseas.
The professor subsequently submitted the article to his university for the evaluation of his achievements for reappointment. The court convicted him of fraud according to Article 347 (1) of the Korean Criminal Act for receiving a publication fee and grant from his university. The court also convicted him of interference with business according to Article 314 (1) of the Korean Criminal Act on the grounds that he had interfered with the business of the university through fraudulent means.

Gwangju District Court decision 2018No244 (decided September 20,2018) reflects a similar criminal case, but with a different result. After hearing the case, the court acquitted the defendant professor, finding that she had not plagiarized someone's work or, at least, had not intended to do so.

\section{Court Cases Dealing with Authorship}

Fourth case: a professor who published a part-time lecturer's book indicating himself as a co-author Supreme Court decision 2007Do7181 (decided December 10, 2009) pertains to a leading case on how to determine authorship when two or more persons are involved in the creation of a work. In this criminal case, the prosecutor accused a professor of infringing the copyright of a part-time lecturer by adding his name as the co-author of a book that had been written solely by the lecturer and subsequently publishing the book. The professor claimed that he had provided materials and files to the lecturer in his role as supervisor, and thus, the book was a joint work. However, the lower courts both rejected the professor's claims and convicted him.

The Supreme Court affirmed the intermediate appellate court's decision, stating, "when two or more persons engage in the creation of a work, only a person who made a contribution to the creative form of expression itself becomes an author of the said work, and a person who did not contribute to the creative form of expression is not considered an author even though he or she participated in the process of creating the work by providing an idea, subject matter, or necessary materials. This conclusion does not change even if the person who is recognized as the author agrees that the person who did not contribute to the work is indicated as a co-author."

\section{Fifth case: ghostwriting master's theses and doctoral dissertations}

In 2017, two professors at a graduate school of oriental medicine were convicted of having received bribes by breach of trust, according to Article 357 (1) of the Korean Criminal Act, as they had accepted money in exchange for conducting the experiments necessary for writing master's theses and doctoral dissertations and delivering the results to graduate students 
via email [4]. The court also convicted the graduate students of paying bribes by breach of trust, according to Article 357 (2) of the Korean Criminal Act, and of interfering with the business of the graduate school by fraudulent means, according to Article 314 (1) of the Korean Criminal Act. In this case, the district court cited the following from Supreme Court decision 94Do2708 (decided July 30, 1996): "if a person relied on another person for most of the work of analyzing and arranging the data and completing a thesis, the thesis should not be regarded as the work of the former, but as the work ghostwritten by the latter." The district court went on to state that when students write theses or dissertations based on experiments, the students are not only responsible for the writing itself, but also for selecting a verifiable experiment method, performing experiments, calculating data obtained from the experiments, and interpreting the results. Therefore, if students rely on others for most of the work mentioned above, the thesis or dissertation cannot be treated as their own work [5].

Sixth case: a professor who allowed his student to fraudulently use his article

Daejeon High Court (Cheongju) Decision 2014Nu5522 (decided August 26, 2015; affirmed by Supreme Court decision 2015Du51545) concerns an administrative case in which a disciplinary measure against a university professor was at issue. The professor had provided a draft of an article to one of his students. The student subsequently presented the article at an academic conference and it was published in the conference proceedings under the student's name. The professor later published the same article in a journal under his name as the sole author. The professor's university suspended him for three months, reasoning that the act of publishing an article that was identical to a paper published under the name of his student constituted plagiarism, and the act of indicating himself as the sole author of the article constituted a misrepresentation of authorship.

In the lawsuit filed by the professor for revocation of the disciplinary measure, the court ruled in favor of the university. However, the court's reasoning differed from that of the university. First, the court held that the professor had not committed plagiarism, as he had not stolen the student's idea or the results of the student's research. The court also held that it was not a misrepresentation of authorship to publish the article under the professor's name as the sole author without listing the student's name as co-author because the student did not contribute to the article. Instead, the court concluded that the university's disciplinary measure was justifiable because a series of the professor's actions had furthered his student's research misconduct and simultaneously caused serious confusion as to the true author of the article.

Seventh and eighth cases: publishing another author's book as one's own with a different cover and title In 2015,179 professors were indicted for changing the covers and titles of books that other professors had authored and republishing the books as their own. The original authors, who had impliedly agreed to this, also were indicted [6]. The court convicted the defendant professors for violating the Korean Copyright Act under Article 137 (1) (i) because they had made works public under the name of a person other than the author. The convictions were affirmed by the Supreme Court in 2017 [7]. Concerning the addition of a professor's name as coauthor to another author's book when publishing a new edition of the book, the court in the first instance held that such a practice does not fall in the category of "making works public" under the name of a person other than the author prescribed by the Copyright Act. In 2020, however, the Supreme Court held otherwise, ruling that such a practice also constitutes "making a work public" under the name of a person other than the author, which is punishable by the Act $[8,9]$.

\section{Court Case regarding Data Fabrication}

Ninth case: retraction of a journal article due to data fabrication

Seoul High Court decision 2017Na2065914 (decided January 11, 2019; affirmed by Supreme Court decision 2019Da207493) pertains to a civil case regarding violation of research ethics due to data fabrication. The plaintiff in this case had published an article in an academic journal in the field of microbiology and life sciences, but was later suspected of violation of research ethics. The academic society that published the journal had an internal regulation that an author suspected of research misconduct had the burden to prove that there was none. Therefore, the academic society requested the plaintiff author to submit the research notes and all relevant data to prove that he had worked on the methods and data of all the experiments published in the journal article. However, the plaintiff claimed that the research notes had been lost while submitting some data for explanation. After reviewing these data submitted by the plaintiff, the academic society concluded that it could not find sufficient evidence to determine that the plaintiff had not violated research ethics. The academic society decided to retract the article and announced via its journal, "The article was retracted due to research misconduct (data fabrication)." The plaintiff, asserting that the retraction of his article constituted a tort on the grounds that it infringed his personality rights and damaged his reputation, then filed a lawsuit seeking cancellation of the retraction and 
Table 1. Korean court cases regarding violation of research and publication ethics

\begin{tabular}{|c|c|c|c|c|}
\hline Related issue & Year & Case No. & Case name & Case type \\
\hline \multirow[t]{3}{*}{ Plagiarism } & 2016 & Supreme Court 2015Da5170 & Affirmation of nullity of dismissal etc. & Civil \\
\hline & 2020 & Gwangju District Court 2019Godan1104 & Fraud, interference with business etc. & Criminal \\
\hline & 2018 & Gwangju District Court 2018No244 & Fraud & Criminal \\
\hline \multirow[t]{5}{*}{ Authorship } & 2009 & Supreme Court 2007Do7181 & False accusation, violation of copyright act & Criminal \\
\hline & 2018 & Suwon District Court 2017Gojung2593 etc. & Giving bribe by breach of trust, interference with business & Criminal \\
\hline & 2015 & Daejeon High Court (Cheongju) 2014Nu5522 & Revocation of the disciplinary measure & Administrative \\
\hline & 2017 & Supreme Court 2016Do16031 & $\begin{array}{l}\text { Violation of copyright act, interference with business, obstruction } \\
\text { of performance of official duties by fraudulent means }\end{array}$ & Criminal \\
\hline & 2020 & Supreme Court 2017Do9459 & Violation of copyright act, interference with business & Criminal \\
\hline Data Fabrication & 2019 & Seoul High Court 2017Na2065914 & Affirmation of nullity of retraction of a journal article & Civil \\
\hline
\end{tabular}

damages of 100 million Korean won in accordance with Articles 764 and 751 of the Korean Civil Act.

The court stated that an academic society enjoys academic freedom guaranteed at a higher level than freedoms of speech and the press, and thus, the academic society's standards for publishing an article in its journal and retracting an article from its journal should be honored. The court also stated that the plaintiff had implicitly agreed to these standards at the time of submitting his article to the journal. The court explained that if there are no research notes (the most important evidence that can prove the researcher actually performed the research), or if important data are missing from the research notes, the researcher cannot prove his/her innocence when accused of data fabrication. The Manual for research and publication ethics in science and engineering states, "The reasons behind the retraction should be as detailed as possible. [...] It is recommended that exact phrases are quoted from the report of the investigative committee of the research institution [10]." In light of this, the court rejected the plaintiff's claim that the retraction of his article and its announcement constituted a tort and ruled in favor of the academic society.

\section{Tabulation of the Nine Court Cases}

The above-discussed Korean court cases regarding violation of research and publication ethics are summarized in Table 1.

\section{Conclusion}

As discussed in this article, research and publication misconduct can lead to various legal disputes, including 1) civil cases, such as affirmation of nullity of dismissal or damages; 2) criminal cases, such as fraud, interference with business, and violations of copyright law; and 3) administrative cases related to disciplinary measures against professors affiliated with a university. Therefore, researchers should keep in mind that if they violate research publication ethics, not only will they be censured, but they may also be held legally responsible for their misconduct.

Research and publication ethics themselves do not constitute laws, but ethical norms that are autonomously established by the relevant academic society. Nevertheless, they become a criterion for case resolution in legal disputes where research and publication misconduct is at issue. This is supported by the Korean Supreme Court's ruling that research ethics refer to "a set of standards generally and universally accepted within the academic community" and the Seoul High Court case (the ninth case above) where the court employed the internal regulations of the academic society as the applicable standard for determination of research and publication misconduct [1]. In other words, to be free from both moral condemnation and legal responsibility, it is best for researchers to adhere to research and publishing ethics.

\section{Conflict of Interest}

No potential conflict of interest relevant to this article was reported.

\section{Funding}

The author received no financial support for this article.

\section{References}

1. Supreme Court Decision. 2015Da5170 (Oct 27, 2016).

2. Supreme Court Decision. 2018Do13696 (Jun 25, 2020).

3. Nam HD. The light and dark sides of the first full-scale Su- 
preme Court Decision on plagiarism. Justice 2017;162:34174.

4. Han YH. A PhD degree costs 20 million KRW, a master's degree costs 10 million KRW: Dean of a graduate school of oriental medicine convicted for ghostwriting. Joongangilbo [Internet]. 2017 Nov 17 [cited 2021 Jan 10]. Available from: https://news.joins.com/article/22126125

5. Suwon District Court Decision. 2017Gojung2591 \& 2592 (Oct 12, 2018) (first trials) ect.

6. Kim DY. 179 Professors prosecuted for misrepresenting the authorship and publication of books authored by others: for the first time. Yonhap News [Internet]. 2015 Dec 14 [cited
2021 Jan 10]. Available from: https://www.yna.co.kr/view/ AKR20151214065251060

7. Supreme Court Decision. 2016Do16031 (Oct 26, 2017).

8. Sohn HS. Court ruling: coauthor falsely added in a book republished. Law Times [Internet]. 2020 Apr 27 [cited 2021 Jan 10]. Available from: https://www.lawtimes.co.kr/LegalNews/Legal-News-View?serial $=161100$

9. Supreme Court Decision. 2017Do9459 (Apr 9, 2020).

10. Hwang ES, Cho EH, Kim YM, et al. Manual for research and publication ethics in science and engineering. Seoul: Korean Federation of Science and Technology Societies; 2016. 